\title{
SELLING OUT OR BUYING IN?
}

\author{
Debating Consumerism in Vancouver \\ and Victoria, 1945-1985
}

In the late 1950s, residents of Vancouver and Victoria negotiated a shopping landscape that would be inconceivable to today's consumers: most stores were closed for at least half the day on Wednesdays, prevented from opening during the evenings, and banned from operating on Sundays. Since that time, however, British Columbians, and Canadians more generally, have made significant strides in gaining greater flexibility in shopping regulations.

Selling Out or Buying In? is the first work to detail the process by which consumers' access to goods and services was liberalized and deregulated in British Columbia in the latter half of the twentieth century. Dawson's in-depth exploration of the debates between politicians and everyday citizens regarding the pros and cons of expanding shopping opportunities challenges the sense of inevitability surrounding Canada's emergence as a consumer society. The expansion of store hours was a contingent and highly contested development that pitted employees, owners, and regulators against one another. Dawson's nuanced analysis of archival and newspaper sources reveals the strains that modern capitalism imposed on the established rhythms of daily life for British Columbians during the post-Second World War period.

MICHAEL DAWSON is professor of History and Associate Vice-President (Research) at St Thomas University. 
This page intentionally left blank 


\section{Selling Out or Buying In?}

Debating Consumerism in Vancouver and Victoria, 1945-1985

MICHAEL DAWSON

UNIVERSITY OF TORONTO PRESS

Toronto Buffalo London 
(C) University of Toronto Press 2018

Toronto Buffalo London

utorontopress.com

Printed in Canada

ISBN 978-1-4875-0220-1 (cloth)

ISBN 978-1-4875-2186-8 (paper)

Printed on acid-free, $100 \%$ post-consumer recycled paper with vegetable-based inks.

\section{Library and Archives Canada Cataloguing in Publication}

Dawson, Michael, 1971-, author

Selling out or buying in? : debating consumerism in Vancouver and Victoria, 1945-1985 / Michael Dawson.

Includes bibliographical references and index.

ISBN 978-1-4875-0220-1 (cloth) ISBN 978-1-4875-2186-8 (paper)

1. Consumption (Economics) - British Columbia - Vancouver History - 20th century. 2. Consumption (Economics) - British Columbia - Victoria - History - 20th century. 3. Consumer behavior - British Columbia - Vancouver - History - 20th century.

4. Consumer behavior - British Columbia - Victoria - History - 20th century. I. Title.

\section{HC79.C6D39 2018 339.4'70971128 C2017-907098-3}

This book has been published with the help of a grant from the Federation for the Humanities and Social Sciences, through the Awards to Scholarly Publication Program, using funds provided by the Social Sciences and Humanities Research Council of Canada.

University of Toronto Press acknowledges the financial assistance to its publishing program of the Canada Council for the Arts and the Ontario Arts Council, an agency of the Government of Ontario.

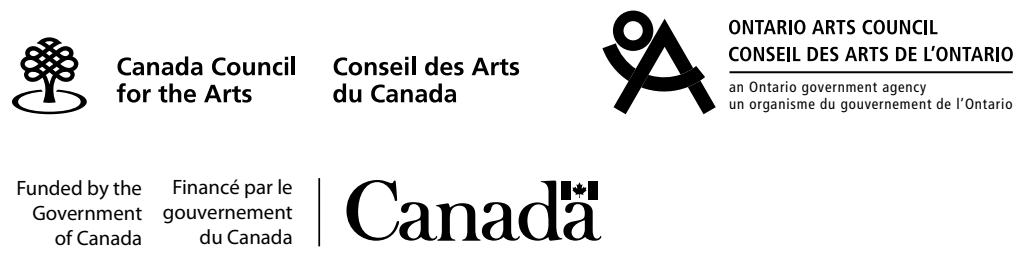

